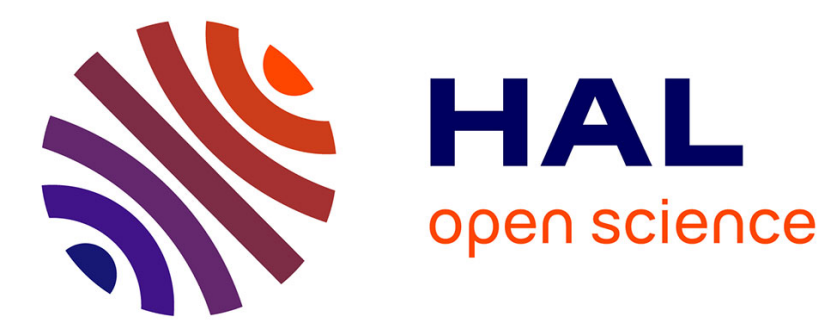

\title{
Dreaming of fecundity in rural society
}

Albert Doja

\section{To cite this version:}

Albert Doja. Dreaming of fecundity in rural society. Rural History: Economy, Society, Culture, 2005, 16 (2), pp.209-233. 10.1017/S0956793305001482 . halshs-00406280

\section{HAL Id: halshs-00406280 \\ https://shs.hal.science/halshs-00406280}

Submitted on 8 Sep 2009

HAL is a multi-disciplinary open access archive for the deposit and dissemination of scientific research documents, whether they are published or not. The documents may come from teaching and research institutions in France or abroad, or from public or private research centers.
L'archive ouverte pluridisciplinaire HAL, est destinée au dépôt et à la diffusion de documents scientifiques de niveau recherche, publiés ou non, émanant des établissements d'enseignement et de recherche français ou étrangers, des laboratoires publics ou privés. 


\title{
$D$ reaming of F ecundity in R ural Society
}

\author{
A L B E R T D O J A \\ College of Humanities, University of Limerick, Ireland \\ and Department of Anthropology, University College London.
}

\begin{abstract}
In Albanian village society, the main characteristic of the social status of women, and their only function that meets social approval, is their aptitude for procreation and motherhood. And the A Ibanian child is first and foremost ason, who will succeed hisfather, inherit from him, guarantee the everlastingness of his lineage and honour his ancestors. If the daughter is a future wife and a potential mother, polyvalent images make the boy child the symbol of radical transformation, renewal and regeneration. The beliefs, rites, practices, the multiple symbolic forms and collective representations surrounding birth and socialisation, in addition to their magic, divinatory or propitiatory roles, are also used to confer a symbolic value of recognition on the processes of construction and socialisation of the individual who has just been born.
\end{abstract}

\section{Household and gender relations}

The social organisation that, until the 1930s, was part of the Albanian way of life and a source of many stories and travel tales no longer corresponds to the sociology of contemporary Albania. L iterature, films, public life and a folklore serving many varied identity claims have now taken over the task of nurturing a host of images concerned with the nation's ethnic and cultural roots. The representations themselves have now become cult objects. Since the 1950s, the imposed communist regime and, in the 1990s, the brutal intrusion into the rural areas of the industrial society and the market economy have managed to finish off what several centuries of political designs had not managed to destroy.

The ethnographic literature indicates that Albanian society shares with other Southeastern European societies a remarkable similarity in their ecological adaptations and social structures, as well as in their ideological expressions. In spite of several ethnicities, speaking different languages and dialects and adhering to threemajor religions, their social organisation has long consisted of fairly closed elementary groups, necessarily oriented by the birth of their individual members. Belonging to a given group defined by kinship, territory, age or gender was part of normal life.

As a rule, the social formations of Southeastern Europe are best elucidated by the notion of 'household', which is less familiar to anthropologists than to historians of the E uropean and $\mathrm{N}$ ear Eastern $\mathrm{M}$ iddle A ges. This notion, found in other parts of the world as well and which was taken up and developed by Claude L évi-Strauss in his last teachings (1984: 189-241[151-194]), does not necessarily coincide with the agnatic lineage; rather 
it is a spiritual and material heritage that includes dignity, origins, kinship, names and symbols, position, power, wealth and privileges. The house is 'a moral person' possessing a domain consisting of material and immaterial wealth, or 'honours', the latter even including goods of immaterial origin, 'perpetuated by transmission of its name, wealth and titles through real or fictitious descent lines which is recognized as legitimate as long as the continuity can be expressed in the language of descent or alliance or, most often, of both together' (L évi-Strauss, 1984: 190[152]).

The basic A Ibanian unit is the shtëpi 'household', also referred to by such metaphorical terms as zjarr 'fire', vatër 'hearth', tym 'smoke', oxhak 'fireplace' (cf. Fr. maisnie, Gr. nikokireta, Rum. gospodãrie, T urk. hane), which can be compared to the Western European medieval term, feu in F rench, which corresponded to 'family'. As a rule, the members of a shtëpi, or 'household', areconnected by kin ties, possess property in common and share life. This gives the family an internal stability and makes it a durable form of social organisation.

The organisation of society has always conditioned the different cultural forms and the modalities of the ceremonies ritualising the personalisation, socialisation and upbringing of the individuals in that society. Birth, the first critical moment in the individual lifecycle, like the later growth and development of the child in adolescence, betrothal, marriage, reproduction, old age and dying, are always endowed with a social value that concerns society, the kin group and above all the family.

It is interesting to see the differences that exist between the rural family based on a married couple with their unmarried children, the pattern prevailing throughout southeastern Europe from $G$ reece to Romania, and the domestic group composed of several married couples, which persisted in part of the A Ibanian population and among the southern Slavs until the mid-twentieth century. I n K osova or in western M acedonia, for instance, households of over a hundred members could recently still be found. E specially in areas where customary law was particularly strong, as in the Malësia e Madhe or $G$ reat $N$ orthern $M$ ountains, the $M$ ountains of $L$ abëria in the southwest, but also in the $M$ yzeqe countryside in the west, until recently one found the large shtëpi comprised of what Claude L évi-Strauss (1956: 77) would call domestic- rather than conjugal-type families. T hese households rested on a complex and rigid organisational machinery. They were characteristically a social group fulfilling at once economic, political, juridical and customary functions (D oja, 1999).

This family organisation is based on a father living under the same roof as his married sons, the sons splitting up only after their father's death. I n comparison, among the southern Slavs the dominant model is that of a family community based on the cohabitation of brothers, even without the living presence of their father. This type of organisation, known as zadruga, has given rise to an abundant anthropological literature, in which it has often been presented as a model of egal itarian democracy within the family, at least insofar as the men are concerned (Sicard, 1943; Byrnes, 1976). T he household, the domestic group, which shared pastoral, domestic and agricultural work, always appears, in the case of the Slavs as in that of the Albanians, as the key component of the social organisation through the symbolic behaviours and manifestations displayed there. $Y$ et, while the Slavic group is organised according to the horizontal principle, emphasising 
the importance of collateral kin, and the primacy of the tangible and contemporary, the Albanian group is governed by the vertical principle, which places the son and what is young, low and present under the father and beneath what is old, high and past.

In Albanian society, intrafamilial relations are marked by a twofold relation of domination: domination of women by men and domination of younger individuals by their elders. The forms of respect are complex and strictly observed. The authority of the head of house is total, even though he does not actually possess absolute power, in the sense that the homestead is collectively owned by the group and no one can dispose of or alienate any goods as he pleases. I n any event, a son will never contradict his father, and still among today's K osovar Albanians, even a son who has gone to university will never leave the family group against his father's wishes, unless he is willing to break with the family and be rejected, which rarely happens.

In any case, patrilineal descent ideology was underscored by norms of partible inheritance, where each brother was entitled to an equal share of the family's property. The dialectic of family dynamics lay in the fact that, while the dominant 'morality' stipulated that joint families should stay together in cohesive productive units, if disagreements over the management of the joint family became irreconcilable, each brother had the right to withdraw from the extended family, to assume control over his rightful share of the family estate, and to establish his own independent decision-making nuclear family and potentially, with the marriage of his own sons, another extended family. But it is not surprising that family division, while commonly practised, was regarded as 'morally bad'. The morality described in such sentiments was a morality of familism. It was a morality of organic growth and development, of common descent and collective destiny, a morality of power which recognised that in numbers there is strength.

Anthropological studies of social morphology and gender among the SoutheastEuropean pastoral populations have indicated the marginalisation of women in such patrilineal groups and in thecultural life of thecommunity, especially in thesedistinctively rural and mountainous areas of Bosnia, M ontenegro, Serbia, K osova, M acedonia, Albania and $\mathrm{G}$ reece. Emphasis on the inferiority of the Albanian woman, for instance, was commonplace in the past. She was traditionally kept in the background and not included in important activities. Among the norms that prescribe the rules of vengeance in the Kanuni i Maleve code of customary law of the N orthern M ountains, the punishment for killing a woman is highly significant: the killer is made to pay only half a blood price (Cozzi, 1910: 661).

Patriarchal society is based on men. The man is the one who gives the family its patronym, leads the group and inherits the homestead. In the Albanian system, there is an essential difference between women's and men's roles. The man's rights have an absolute character, as prescribed in all accounts of customary law. A woman can never, under any circumstances, inherit property (G jeçov, [1933]1989: 264). I f the household is without male descendants, it dies out, and its lands are divided equally among the other households, which have equal rights since they occupy the same position in the lineage. If the family is without close kin, the set of clans or the lineage, 'even at a distance of a hundred generations', has equal rights in the inheritance (G jeçov, [1933]1989: 96-97). 
When a woman marries, she leaves her own family and goes to live with her husband's people. $\mathrm{H}$ er children will belong to his line, whereas she herself will al ways be an outsider, mall $i$ huaj, 'others' goods', especially in N orth Albania. In traditionalist discourse, Albanian women are described as 'the property of men, to be bought, sold and betrothed before birth' as just 'sacks to be filled' (G jeçov, [1933]1989). It is only when she gives birth, that she will be recognised as a fully fledged wife. U ntil then, she could still be repudiated. In Southeast-E uropean pastoral societies only as the mother of sons does a wife secure a place in the group, bound to it through a blood tie. T he marriage becomes final, as L évi-Strauss (1956: 75) stressed in writing about several comparable societies, only when the woman has borne a male child. A variant of this theme, especially in rural areas with more patriarchal belief sets, is the hope for sons because only a male heir can perpetuate the patriline and is able to perform the rites that give honour to ancestors. It is only then that the marriage has fulfilled its most essential function, which is to carry on the husband's line.

At any rate, an Albanian husband, usually seconded by his own group, treats his wife differently depending on whether she is merely a wife for him or whether he sees her as the mother of his children. The main feature of the woman's social status and her only socially valued function are founded solely on her capacity for procreation and motherhood. F ertility is the prime quality that enables her to be considered by others, and to consider herself, as a fully fledged individual. The process of her socialisation is meant to satisfy a single desire: to become a mother, illustrating a strong relationship between the birth of children and the socialisation of their parents, which is also found elsewhere in the anthropological literature, for instance among the Zafimaniry of M adagascar (Bloch, 1993). In the norms laid down by the Kanuni $i$ Lekë Dukagjinit code of customary law (G jeçov, [1933]1989: 64), it is explicitly stated that vajza pa u ba nanë s'asht e zoja e vedit, literally 'the young woman who does not become a mother is not mistress of herself', in the sense of not being a person in her own right.

The destiny of the Albanian woman is al ways embodied in her status as a mother, in other words in her barku, 'womb', a common term that designates the children a woman has borne as well as the maternal line. If she gives birth to many healthy children, she will at least be recognised as having ensured the continuation of the line and the lineage. As can be seen in most of the Albanian documents, from the $\mathrm{N}$ orth as well as from the South (D oja, 1991: 133-135), a woman's prestige is measured in terms of the number of children, especially male children, she gives the family, the line and the kin group. $M$ otherhood has given the A Ibanian woman status, social esteem, identity, and affective and economic support.

A woman is regarded 'unworthy' and of little account if she cannot give her husband children or otherwise enhance the honour of his family. The fate of infertile women is indicative, as they remain isolated within the group, unable to forge blood ties with it. A barren woman is often held in contempt and she is regarded as an unfinished being, someone who is incomplete and totally deficient. Sometimes she was replaced by another wife, especially in the $\mathrm{N}$ orth. I nability to conceive is automatical ly the woman's fault, everywhere and always. People speak only of female sterility. The bulk of the anthropological literature dealing with the subject has little or nothing to say about the 
existence of a specifically male sterility, not so much because the authors have always applied their own cultural assumptions to the documents they have collected as because this is the way the information was formulated by the informants themselves (H eritier, 1996: 87-132).

\section{Elementary symbolism}

$\mathrm{H}$ istorical and ecological contingencies, difficult economic conditions and a precarious livelihood favoured the deep-seated sentiment of the need for socialising kin relations. In this kind of social organisation, the individual's life was closely bound up with that of their family, and the success of a marriage was measured by the number of children. A large family ensured the continuation of the line. F or the prosperity and the advancement of families depended, among other things, on the amount of available labour, which was the most precious capital. Children become productive at a very young age for small chores. As the labour force is ensured only through births and marriages, the birth of many children is often regarded as a good investment. Such sentiments are expressed particularly in the parents' desire that their child have as many brothers as possible and spend his life in a veritable network of the widest and most durable kin alliances and friendships. This conception, strongly rooted in the psychology of Albanian mothers (Shala, 1983: 98), is represented particularly in their lullabies (e.g. D oja, 1991: 276).

This is part of the common matrimonial strategies, clearly expressed in the case of marriages in which one gives one's daughter preferentially to someone who has many brothers and is known to belong to a strong and numerous line. As patrilocality is the dominant tradition among Albanians, in the perspective of 'doubling one's capital' through marriage, the birth of male children is openly preferred and occasions great joy in the family. F or the same reason, the birth of girls is not greeted with visible joy, and often quite the contrary.

Similar representations of the social gender division can be found throughout the different cultural forms of the traditions surrounding birth and socialisation. The Albanian child is first and foremost a son: he will succeed his father, inherit from him, secure the continuation of the line, and above all honour the ancestors. The daughter, on the other hand, is a future wife, in other words a potential mother, but is destined to ensure the descent of another, alien, line. A s a rule, the ceremonies, thedifferent practices and the symbolic forms surrounding the anticipation and celebration of the birth, development and education of the children in a family are clearly differentiated according to the child's gender (D oja, 1990).

T his contrast is particularly stark in the congratulations that greet the newborn child. Before the birth, everyone unfailingly hopes for a male child. Socially speaking, the mother too always hopes her child will be a boy, although sometimes sentimentally, especially if she is already the mother of several boys, she may hope for a girl. If the child is a boy, people wish him a long life, but if it is a girl, people congratulate the mother on her safe delivery instead. F urthermore, people used to believe that the birth of a girl brought such bad luck that they sometimes greeted her with regular curses or ritualised condolences. Mos u rrittë! 'M ay she not grow up!', Si e patët kët idhnim? 'H ow 
could such a misfortune befall you?', Mos u prishni se Zoti i fal si djemtë si vajzat! 'D on't be sad, the good L ord gives boys as well as girls', or Çika përkund djalin! 'T he girl is born to rock the boys!', etc. T here are indeed many superstitions surrounding the birth of a girl. I $n$ the region of $K$ orça, in southeastern Albania, for instance, if the newborn child is a girl, they say that the weather will turn bad, the fire will no longer light in the fireplace, the roof tiles will turn black, the roof beams will break, and so on (F rashëri, 1936: 30).

Për çupën e parë sëkëlldiset shtëpia, për të dytën qajnë trarët e shtëpisë, për tëtretën strehët pikojnë vrer, për të katërtën e kusur,

ka lijë! ka fruth! ka murtajë!
When the first daughter is born, the household is tormented, when the second is born, the beams of the house weep, when the third is born, the canopies drip with gall, when the fourth and more are born,

there is pox, there are measles, there's the plague!

The birth of the first boy, called in several regions the 'only son' për mall, dëshiri or hasreti, ensures that the name will be preserved, that the line and family will continue, and that it will be strengthened economically and the parents cared for in their old age. Absence of a son has always occasioned, if not actual difficulties, at least dissatisfaction and vexation. A family without a male heir always feels defective and an object of pity in the eyes of others, kin or not (Zenku, 1972: 110). N o doubt in this case the couple could lead a normal life and meet their needs, L évi-Strauss writes, but many societies refuse them their full place, not only within the group, but beyond, in the society of the ancestors, which is just as important if not more than the society of the living. F or no one can hope to achieve the rank of ancestor without descendants to render them a cult (L évi-Strauss, 1956: 74).

The belief that the soul of the deceased goes on a long journey is shared by all Southeast European peoples. The soul travels through dangerous zones, its path is both long and strewn with pitfalls. T he soul is in need of help from the living, failing which it will never reach its destination, but will wander in torment. A lost soul is a danger to its family and its whole community. The deceased becomes a vampire that destroys the village crops, dries up the cows, causes a series of deaths and other misfortunes. M oreover, a house without a master attracts evil forces. T hroughout Europe an abandoned house is presumed to be haunted. The icons that were left to guard abandoned houses all over southeastern E urope until the start of the twentieth century attest to the fear of the house being possessed by evil powers (Stahl, 1981: 48-49). I n effect, the society of the hereafter resembles that of this world. Whoever has no children to help him will be alone even after death, alone for all eternity.

R ecent studies on marriage have been preoccupied with description of kin relations and property ownership, or by the symbolic analysis of ceremonies; they all too often forget that the primary purpose of marriage is to have male children so as to ensure the biological survival and the continuation of the domestic group (Stahl, 1981). D ifferent rituals, often modeled on agrarian fertility rites, arefrequent, notably during the marriage ceremonies. T he seeds, fruits and coins that are showered on the newlyweds, and the wedding cake are all aimed at precisely that purpose. Other rites and practices are intended more to ensure the birth of male children: for instance holding a little boy up to the bride when 
she enters her husband's house for the first time, placing men's hats on the bride's head, rolling a little boy in the couple's bed on their wedding night, as well as other similar rites and practices that have been recorded as elements of A lbanian wedding ceremonies (D ojaka, 1986). O ne of the most widespread formulae among A Ibanian populations is the wish u trashëgofshi!, literally 'may you have heirs!', which is addressed to the newlyweds with the sense of may you 'grow old together and have many children, especially male, so as to perpetuate the line'. T he wedding songs underscore similar formulae and practices.

T he fate of the Albanian woman is bound up in one way or another with the history of her biological misfortune, should she be sterile or bear children who are sickly or die at birth. The underlying biological facts may well seem to be easily perceptible and a part of the universal corpus of observations on human nature conducted by all societies. I $t$ is the woman who bears children, carries them, feeds them over the course of a fertile period marked by a visible onset, first menstruation, and by the end, menopause. If a woman has never become pregnant during this period of her life, it can only be due to her own personal nature.

In Albanian tradition, the supposed causes of sterility almost always reproduce the representations of the person and the society. Consequently sterility underscores something about gender relations. Even though sometimes, as among the Albanians of I taly in F rascineto-Ejanina, responsibility for sterility is attributed to the husband as well, the fault is ascribed to the mother only if the children are stillborn or die at birth (Giordano, 1976: 8). A woman who is barren or whose children do not survive can sometimes be held responsible for her destiny insofar as she is believed to have, deliberately or not, committed transgressions that are signified by the stigma of sterility. F urthermore, these are almost al ways social transgressions.

W hatever the case may be, it is striking to see how rarely people are totally resigned to such a fate: it is imperative to find a cause and a remedy at all costs. T he women themselves cling to their identity by their desire to become mothers. Everything that might go against this destiny, at whatever level, should be set right. T he elders and the various distarë, traditional 'wise men', the priests, no matter what their religion, are all called upon to help. $\mathrm{N}$ ot only the woman, but also her immediate family, kin group and neighbours do their utmost to put a stop to this scandal of barku $i$ thatë, the 'dry womb'. D ifferent magical and religious forms and practices have an important part. $T$ hey figure among the vestiges of ancient phallic and agrarian cults in which earth, water and air, but also the plant and animal realms, play a vital role as agents of fertility, not to mention sunrays and moonbeams, zodiacal calculations and votive pilgrimages (D oja, 1991: 39-46).

In the T etova $\mathrm{H}$ ighlands, an Albanian cultural region located in western $\mathrm{M}$ acedonia, when a woman was sterile, or when a woman was unable to carry her pregnancy to full term, or when the children did not survive after birth, people $u$ kthenin plis, 'turned over a clump of earth', in accordance with a complex ritual, described by Fadil Suleimani (1988: 18). Early on the morning of Saint G eorge's D ay, the sterile woman goes with one or several women to a grassy spot and there lies down. One of the young women takes a spade and digs a narrow trench around her body. The infertile woman gets up and the whole patch of ground inside the circle is turned over to see whether it contains 
the slightest sign of life, insects or other living beings. If some small worm, ants or other life-forms are found, it is believed that the woman will become pregnant. She then places these living beings in a small box or wraps them in a piece of cloth and wears them on her person, convinced that she will now be able to conceive a child.

The semantic field of the general symbolism covered is that of the earth in all its senses - mother earth, land, the ground and the soil, in the first place - with its multiple aspects and affective associations. E arth symbolism, especially when it comes to the I ndoE uropean area, embraces the entiretradition of practice as well as the wholecircle of man's desires and dreams, from fertility to the continuation of the generations (Eliade, 1949: 208-228). The myth of $M$ other-Earth, the earth who feeds her children, source of all fertility, deeply permeates the rural mind. All questions about the origin of life and the growth of plants, animals and beings comes back to the myth. T he earth preserves and transforms, it initiates and brings to perfection; it holds souls in reserve, brings species to their maturity, receives bodies when life has left them. I ts lavish womb unceasingly ensures the permanence of the life-cycle.

$Y$ et earth symbolism has al ways shown this tendency to polarise antagonistic values. T hefertile earth of farmers, the cultivated, devel oped, well-ordered earth is at once man's refuge and his possession. I $\mathrm{t}$ is al so the earth in which vegetation dies and is reborn. It is at the same time primordial, virgin, original and elementary, black and savage, chthonian and associated with death. The polarisation of this symbolism regularly swings from primordial matter to cosmic earth, then back to a chaotic phase, marked by the passage from one season to the next.

W emust al so place on the nocturnal chthonian level, which is associated with the moon and plant life, what Bachelard has called the 'valorization of mud' (1948). T he primordial earth, with its slippery, muddy, sticky character, has becomethesymbol of copulation and regeneration of life. Such a principle must have acted in the same way when Albanians 'turned over the clump of earth' on behalf of sterile women. This practice must have symbolised a certain contact with chthonian powers, which gave rise to orgiastic dreams of impregnation. T he descent into the shadowy depths of the chthonian world, on moonlit nights among the plant roots, becomes the representation of a mystical participation in the very heart of matter.

Contact with the chthonian world and the nocturnal dreams of fecundity in the depths of the earth reveal another aspect of inner matter, one which is chaotic and turbulent. A passive earth would be unable to survive human practices. $M$ an was forced to work the earth. It was proper that, after the chthonian disorder of the seeds, the roots, the winter grubs and the living beings poshtë plisit 'under the clump of earth', should come the regeneration of spring and the harvest, life and hope. The living beings kept in a box or folded in a piece of cloth by the sterile A lbanian woman must have symbolised, in the terminology of G ilbert D urand (1969), the principle of the circular rhythm of the passage from the symbolic representations and images of a nocturnal system to those of a diurnal system, a passage designed to determine not only the fate of plant life and the seasons of the earth, but also the fate of fecundity of the woman.

A ncient $G$ reece expanded on the metaphor of the procreativewoman as a fertileground. In mythology, man comes from the earth, he springs from the earth like a plant from the 
ground, or like a child from the womb. T he twin analogy, which equates the earth and the womb, the plant and the embryo, was already widespread in G reek thought. T his metaphor, transmitted, rediscovered or reinvented, is given an original twist in a set of beliefs, practices and rituals connected with the month of $\mathrm{M}$ ay, frequently attested in E uropean cultures from the $\mathrm{M}$ iddle $\mathrm{Ages}$ to our own time. T he procreating woman is depicted as a piece of land, and the piece of land, in turn, eminently the native land, is presented as a mother. T hese representations have provided a symbolism referring now to one, now to the other. I n K orça, in southeastern Albania, it is in M ay that certain plants are gathered in three fields, they are laid out on a large hot stone on which the sterile woman sits, when she is not menstruating, in order to become pregnant; or the plants are thrown into her bathwater (F rashëri, 1936: 29). I t is al so on Saint G eorge's D ay that kthejnë plis, the 'clump of earth is turned over' for the sterile woman. T his ancient feast day, which was the expression of kthimin e dimrit për verë, literally the 'turning', the turning of winter into summer, the renewal of nature, marks the beginning of work in the fields and pastures (H axhihasani, 1988: 56).

O Shën Gjergj i hardhë,

Oh Saint G eorge the Blithe, njishti motmot m'gjeç me djalë! L et me give birth to a son next year!

At dawn, when night kthehet, literally 'turns around' and gives way to day, the young girls and the young brides go into the grassy fields and roll on the ground in the hope of fulfilling their desires and dreams by this contact with the chthonian powers. The young girls hope to find good fortune in marriage, the young brides, to find happiness in motherhood. T hrough the shati, 'big spade', which kthen plisin, 'turns over the clump of earth', the representation of this good luck is also permeated with a deliberately metallic, dynamic, aggressive, masculine valence, like the valence of the ploughshare in general earth symbolism. L ike the earth, the image of the woman's fertility can be transferred to the diurnal system only through the agency of an outside power. T he land is masculinised by the ploughshare, plisi, the clump of earth is masculinised by the shati, the 'spade', the woman is masculinised through ritual practices. The images of metal tools and male work were also a symbol in which the desire for fertility and abundance was formally expressed.

I n other cases, the living beings taken poshtë plisit, from 'under the clump of earth', are placed in abath in which the infertile woman bathes so as to havechildren. Sometimes they are dipped into a small amount of water, which she then drinks so as to conceive. Since the most ancient times, in the E gyptian civilisation and the pre-Colombian neolithic cultures, as M ircea Eliade (1949: 165-187) tells us, the hieroglyphs for water were emblems of a broad anthropo-cosmic constellation in which wetness, the woman and the phases of the moon were combined to depict fertility. It seems altogether natural that, from the beginning, man had noticed the connection between rain, moisture, watering and the natural abundance of plant life. The images of the sky with the rain-bringing storms and the images of the moon with its phases that mark the revolution of the heavens and the tides feature especially in their nocturnal state, in other words in the coolest part of the twenty-four hour cycle, when moisture condenses into dew. It is notably this coherent series of images that has set the tone for all earth mythology and symbolism in which 
the different dramatic, productive and biological cycles of man's everyday life are played out and contrasted. The heavens and the moon thus enter quite naturally into the great emblematic set of fertility images.

On moonlit nights, in particular, infertile women in the region of T irana go to the $e$ bekuar 'blessed' fountain of Bathore, where they wash in the water while singing verses and litanies to get a child (D oja, 1991: 44). T he infertile women of T irana and $K$ avaja, Christians and M uslims alike, would also go to bathe in the sea at $D$ urrës. I $f$ the waves washed over them, they believed they would become fertile (Çabej, 1935). T he same practice was also followed by sterile women in other regions further from the sea, notably in K orça, in southeastern Albania. They would set out in mid-A ugust for the shores of $D$ urrës in the hope of having children ( $F$ rashëri, 1936: 29).

T o the general symbolism of water as a fertility principle, Gaston Bachelard (1942) added the antinomic configuration of water as both male and voluptuous, and female and maternal, capable of appeasing passions and satisfying desires. I ndeed fecundity does result when rainwater or springwater mixes with the male symbol, when either uji 'water' or shiu 'rain' (both masculine in Albanian) fall on infertile women. F ecundity can also result from the immersion of the woman in water, water and mud being the primordial female womb from which all forms of life spring (D oja, 1991: 44).

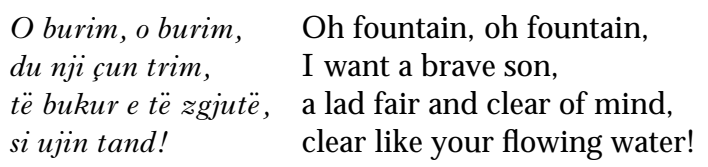

Whether masculine or feminine, water was the primal undifferentiated origin of fertilisation. If we follow the interpretation proposed by N icole Belmont (1980) of the myth of the child exposed on the waters, we gain access to an additional meaning of water symbolism. According to this interpretation, it is no longer a question of a birth by inversion of the terms, 'enter the water/leave the water', as, following F reud, Otto Rank suggested in Der Mythus der Geburt des Helden ([1909]1952), but something like an inverted birth, in which we re-enter the water, return to the maternal waters, return to whence we came. The essence of the myth, its aim and function, is to explain the mystery of origin: namely the appearance of life. To do this, the creation myth quite naturally makes use, as Bachelard saw, of the 'alchemical' theme of the mystery of the transformation of the elements, and thus invents metamorphosis myths. Follows the still deeper mystery, the 'divine' theme of the transmutation of matter into life.

\section{Divination}

T he symbolism of birth and the dreams of fecundity as well as a large set of legends, narrative traditions and ritual practices of various origins all seem to point to belief that women can have children, if not without having undergone human insemination, at least by means of magical impregnation. Supernatural or magical impregnation is a widespread theme of myths and tales. In A Ibanian tales, pregnancy can come about by eating blueberries, mandrake root, apples, insects, and so on, or by drinking different beverages; it can al so be caused by supreme powers, come about after having contracted 
an extraordinary pact with the devil, witches, wild animals, etc.; it can be caused by an intense desire, a dream, sunlight and moonlight, rain, wind, fire, blood, saliva, by a scratch or an encounter with an animal, bathing, etc. (D oja, 1988). Evidence of similar practices can be found in archival data from questionnaires and ethnographic reports compiled since the early nineteenth century, which are deposited in the Ethnographic A rchives of the I nstitute of popular Culture in T irana, as well as in my own fieldwork in several Albanian areas.

I $\mathrm{n}$ the $\mathrm{T}$ etova $\mathrm{H}$ ighlands, women make a votive pilgrimage to a reputedly holy grave with the intention of becoming pregnant or being able to carry a pregnancy to full term. T hey circle the grave three times repeating special verses and formulae (Suleimani, 1988: 17-18). I $n$ the region of $M$ ati, in northern A Ibania, they even go so far as to undress near a grave (T irta, 2004: 234-240), but more often they take away from the tomb a small stone as a sort of promise and guarantee or they drink water from a gourd left overnight on the tomb. T hey must return the pebble six weeks after child birth, together with something in the way of recompense as a counter-gift.

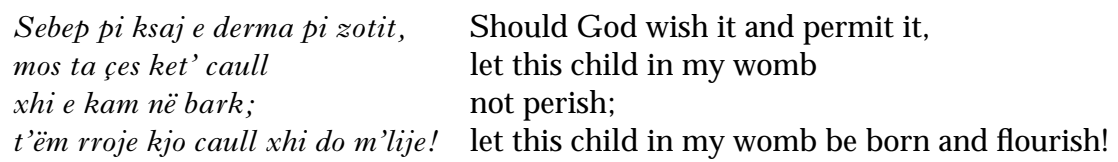

T he same objective is present more particularly in the explicit themes of the different symbolic forms and practices designed to ensure the fecundity of the marriage and to forestall sterility in the woman through the symbolism of fecundity. The different practices designed to promote pregnancy and prepare the birth are significant, too, of the indirect way in which they evoke fecundity, fertility, prosperity and plenty. T he themes of the poetic forms of oral expression, for example, most often have to do with fertility and the continuity of life through enlargement of the family and the kin group (Doja, 1991: 39-55). T his principle is illustrated in the 'T he $\mathrm{D}$ ance of the $\mathrm{N}$ ew M other' Vallja $e$ Lehonës, by the big family circle with nine sons and nine daughters-in-law, and such other images of prosperity as the golden cradle, silken swaddling clothes, layettes embroidered with fil de moulinée, the gold spoon, fat loaves of bread, the fresh leg of lamb, the creamy goats milk, etc. W hiletherefrain Të voft barku marë lihon-o!, 'Blessed be the birth, oh lady in labour!' has condensed the semantic and functional essence of the dance into general good wishes for new mothers, with their magical powers, uttered at specific points in the ritualised birth ceremonies (D oja, 1991: 39-43).

Ti, e shoqe e Allaj beut,
që na lindi nandë djel,
nuk kishte shpërgaj
me se t'i lidhte.
Po me shpërgaj të mëndafshtë!
Të voft' barku mar', lihon-o!
Ti, e shoqe e Allaj beut,
që na lindi nandë djel,
s'kishte djepe

Y ou, the wife of Allay Bey, who gave birth to nine sons, had no swaddling clothes, in which to wrap them, to swaddle them in silk! Blessed be the birth, oh lady in labour! $\mathrm{Y}$ ou, the wife of Allay Bey, who gave birth to nine sons, had no cradles, 


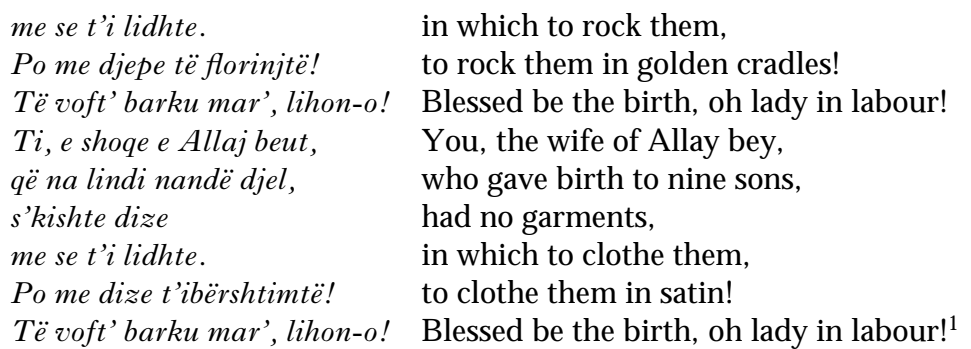

T he same principle is echoed in the songs dealing with the preparation of the layette and the cradle for the new baby ( $D$ oja, 1991: 53-55), the pride in the fecundity of the mother and the family, and in the image of the augmentation of the oxhaku, 'fireplace', meaning the family 'hearth', by numerous male children. With the same intention, throughout the traditional ceremonies and practices surrounding birth, songs of love, marriage, immigration, narrative ballads and other epic and lyric genres are sung. T hesegenres may show signs of contamination by birth songs, as certain documents recorded by Albanian folklorists prompt us to note. T his must have some connection with the relatively magical character of the poetic genres when it comes to expressing hopes and desires. In these cases, they may be used, with somefunctional modification of their primary meaning, to compensate the relative lack of birth songs.

The beliefs, rites, practices and other cultural forms of symbolic expression surrounding birth aim, among other things, at predicting or anticipating and predetermining certain bonds which in some way are regarded as desirable and favourable to the construction of the person and to the future socialisation of the child in the womb. In most cases, however, insofar as the child's sex is concerned, among Albanians as in other European cultures, it is more a question of signs and divination procedures than of rituals designed to obtain the desired sex.

F or example, many signs can be read on the mother's own body. This gives rise to a theory about the relationship between her body and that of her child. T hese are especially the shape of the belly, but also her overall appearance during pregnancy. The male and the female foetus lie differently. They also act differently on the mother's psychology. G enerally speaking, bad signs almost always predict the birth of a girl: liver spots on the face, acne, morning sickness, badly tolerated pregnancy, etc. On the other hand, a blooming pregnancy is generally associated with the birth of a boy ( $\mathrm{D}$ oja, 1991: 49).

Djal' po duket n'hijeshi, by the fine look of it, a boy so it appears,

n'hijeshi që barra ka! . . by that fine look of pregnancy!. . .

Referring to data stemming from F rench culture, F rançoise L oux (1979: 163) thinks that observations of this kind draw their meaning from letting the woman's body behave mechanically so as to see which of the culturally non-regulated attitudes or appearances will prevail, and to associate an aspect of the body with a sex, thus causing the physical

1. U nless otherwise indicated, all translations from theA Ibanian have been made by R obert E Isie, in collaboration with the author. 
appearance to reveal what the body conceals in its inner recesses. H owever, if we look at the A lbanian evidence, it is not so much a case of the body providing the interpretation as of the socio-cultural code assigning a meaning to the signs of pregnancy, including the mother's own physiology. Although her feelings incline her towards the birth of a daughter, this goes against social expectations, which on the contrary demand that her child be a boy. This imperative is inscribed on her body, whose interpretation can be read only within the same socio-cultural code that is the basis for all of society's collective representations.

T he beliefs and customs concerning prediction and divination are likewise connected with certain features of the birth or birthmarks on the body of the newborn child. E merging feet first, for example, is generally seen as a bad sign for the child itself, although this has more to do with the attitudes and behaviour it will display in society than with its personal destiny. T here is such a strong belief that the child born feet first will be badly behaved and become the scourge of the group that, if someone seriously misbehaves in a situation, people will say that he must have been born feet first. T he beliefs connected with inverted births must surely be attributed to the well-known representations of death as a reversal of the axis of birth (Belmont, 1971: 129-160).

Albanian tradition has many more signs that foretell the child's sex. Omens relate future births with past births. In the T etova Highlands, for instance, at the ceremony known as kokrra, literally 'grains', cel ebrated on the occasion of a birth, in order to predict up-coming births, a handful of corn was boiled and the kernels eaten, two by two. I $\mathrm{n}$ the end, if three kernels were left, it was believed the next child would be a boy, if only two remained, it would be a girl (Suleimani, 1988: 17).

Me numrin tek besohet se do të lindë djalë, pasi djali nuk pjell, nuk shton, është tek güthnje, kurse me numrin çift besojnë se do të lindë vajzë, vajza pjel dhe shton, duke u bërë çift giithnjë.
If the number is odd, it is believed that the baby will be a boy because men do not give birth and do not reproduce by themselves, the man is al ways an odd number. An even number is a girl, for women, on the other hand, give birth and reproduce by adding up to two, by duplicating herself.

T his indicates a qualitative understanding of numbers. I $n$ this conception, the quantitative aspect is not overlooked, but it refers to a concrete role. T he qualitative aspect, on the other hand, seems to be the vector of an abstract mediation. As in André L eroiG ourhan's work in prehistoric anthropology (1964) concerning the more or less complex sets of dots, crosses, arrows, chevrons, cross-hatchings, etc., featured in many walldrawings, carvings or reliefs, one wonders if the customs concerning the prediction of the future child's sex may not, like the carved figures of geometric art, be part of a symbolic logic articulated around the male/female opposition.

Qualitative numeration, in Albanian tradition, could also be compared to certain categorical figures found in African societies. Parallel to and in accordance with the same thought system that governs their oral tradition, these societies have made oriented representations of their cosmogony: in particular, altars, standing stones, small constructions erected in caves or in a hollow beneath a rock in which some wall panels are sometimes covered with polychrome paintings. F requently the number of dots, lines, sectors of a figure, as well as the number of figures themselves is by no means indifferent. 
T he study and commentary that accompany these abstract signs, the theoretical dots called 'marks', in which once again numbers, diagrams or sketches feature, like all of the realistic polychrome figures, show that these societies possess a cosmo-biological theory of destiny and its variations and its evolution over time as well as its functions (G riaule and D ieterlen, 1951).

F or A lbanians, too, with their patriarchal inclinations, qual itative numeration is al ways supposed to bring happiness, good luck and prosperity in one's life and work. F or instance, in nearly every region, the major birth celebrations take place preferably on the third day after the birth, or on another odd-numbered day, the first, fifth or seventh. I t was believed that in this way, following the sameline of reasoning based on the symbolism of qualitative numeration articulated around the opposition male/female, that life would remain open so that reproduction might continue.

The birth celebration is first and foremost a happy time for the circle of family and kin, a sign of their satisfaction and joy at the birth of a male child. In some cases, its organisation points up the representations of the gender division. The size of the celebration, for instance, is conditioned by the greater or lesser age of the parents, but above all by the birth of the first-born male child, by the birth of the heir, by the birth of a boy after several girls, etc.

The time of the celebration expresses the same logic. F or instance, in the T etova $\mathrm{H}$ ighlands, if the child is a girl, haste is made to organise the babina (one of the chief ceremonies celebrating a birth) so as to break the series of female births, but up to six months or a year is allowed to elapse after the birth of a boy, so as to increase the number of male births (Suleimani, 1988: 39).

In some cases, in the region of $L$ uma in northeast Albania for example, the mother leaves her bed three days after bearing a girl, whereas if she bears a son, she can allow herself to wait five or seven days (H oxha, 1961: 246). I n the north, the ceremony for the mother is performed four or six weeks after the birth if the newborn child is a male, and three or five weeks later if the child is a female (G jeçov, [1933]1989: 436). T he reason for this is again an omen or the predetermination of future births. D uring this time many women usually pay visits to the new mother. They bring her presents of money or items of layette for the child, but also eggs: an even number, two, four, six or eight, if it is a boy; and an odd number, one, three, five or seven, if it is a girl (D urham, 1928: 191).

T he same reasoning applies here, based on the symbolism of qualitative numeration articulated around the opposition male/female, but theterms of the opposition arealready reversed. T he passage from the moment before the birth to the moment after, from the child not yet born to thechild just born, is marked by areversal of the symbolic procedures. $T$ he sex of the social person is expressed by an odd number before the birth, when the child is not yet born, when it is hidden, or when it has not yet been received into the group as having been born. It is expressed by an even number after the birth, when a male is there, visible, when he has been biologically and socially born.

\section{Psychosocial mythology}

Birth itself is no doubt a particularly dreaded moment, for it is dangerous for both mother and child; it is a dramatic moment, with all its bustle, cries, waters, heat. Y et in European 
cultures, 'we do not find many recipes for ensuring that the birth goes well' (L oux, 1979: 146). In these societies whose religious structure is more coherent, more conscious than in Albanian culture, the only objects that might be used to help the woman in labour, especially if it looked like it would be long and hard, were often holy pictures, which were suspended above the bed, representing one of the patron saints of child birth: Saint $M$ arguerite or Saint Anne, with prayers under the effigy specifying the reasons for invoking the saint. Sometimes other objects would be placed next to the woman in labour, even on her abdomen, so as to give concrete and palpable reinforcement to the abstract role of prayer. These could be small books containing prayers, always the same ones with few exceptions. So-called 'childbirth sachets' could also be used; these were small cloth pouches containing, once again, a prayer or a religious picture. $T$ he future mother could also tie around her waist a silk ribbon of a very specific length: 'the measure of the Cross of J esus Christ', or more often 'the measure of the true girdle of the Virgin', usually designated by a term recalling the nativity or Our $L$ ady of $L$ abour. $M$ edallions featuring the Virgin or Saint Anne were also pinned on the young woman's chemise. Prayer was usually combined with a number of other healing procedures, so that it was actually regarded as one of many remedies. It was never a simple discourse addressed to an ethereal god ( $L$ oux, 1979: 146-154).

In Albanian tradition, before the birth, the woman was led to the village fountain, where she was made to step over the stream of water so that the child might be born quickly and painlessly, like running water. If the fountain or stream was far from the house, or the woman was unable to walk, running water was suggested by pouring water from a pitcher onto the hearth. I n other cases, a woman would go without saying a word, to the fountain and fill her mouth with running water, which she would let run on to the face of the woman in labour so that the child might be born as quickly and easily as the water that runs down her face. She might also be given a drink of water from the millrace so that the powers of the water would help the child come into the world just as they move the wheels of the mill (Suleimani, 1988: 20). I n each case, the symbolic significance of water stems from the fact that birth is an aquatic passage, just as the path taken by the child is represented in mythology as a rushing stream.

At the time of her delivery, the woman's hair is untied, untangled and combed down her back so that she too will be untied, untangled and may be delivered of the child. T hese practices can be compared, among others, to certain beliefs current in Ancient Roman society. J uno is the most important goddess in Roman mythology and religion. She is the female companion of J upiter, queen of the heavens and patron of women. As L ucina, she brings children into the world. She was invoked for childbirth and received offerings in return. Dumézil draws our attention notably to a temple, Funonis Lucinae, dedicated to the goddess, where 'in view of an easily understood symbolism, no one is allowed to enter if he has a knot anywhere in his clothing' (1987: 301). The goddess was also known as Solvizona, 'the one who unties girdles', and when a woman was pregnant, she was supposed to leave her girdle in this temple (Belmont, 1971: 161). During the birth, nothing must be left closed in the house, all locks are unlocked, and everything that might be closed is opened: boxes, drawers, chests, doors, etc. with the intent to open the way for the child. Even the items of the layette 
prepared for the child, swaddling clothes or blankets, undershirts, etc., are unfolded and sorted out so that the mother may be delivered of the 'gravidity' of the child. It is interesting that the Albanian term for pregnancy, barra, puts the stress on 'gravid' and 'weight'.

The branches of the mulberry bushes, walnut trees or other trees close to the house that readily drop their fruit are beaten, likewise with the intention of prompting, helping and speeding the birth of the child. A stick is also shaken threateningly over the head of the woman in labour to intimidate the child in her womb, make it move and come out promptly (D oja, 1991: 59).

If it happens that, even after all these practices, the difficulties and the pains of labour continue, the woman is laid in a cradle, or in a packsaddle set upside down, and she is rocked, as one would a child. T his more or less obstetrical procedure has taken on a highly symbolic connotation, since the cradle is the place where the infant is laid, just as the packsaddle is the attribute of the horse, whose rapid movements could, like the cradle, increase the speed of the birth.

In most cases, however, the responsibility for a difficult birth falls squarely on the expectant mother. I nterpreted retrospectively, the difficulties are usually ascribed to her previous behaviour. As a mother-to-be, that is as the one who is giving birth to a new member of the family and the kin group, it seems 'normal' that she should be held responsible for the anomalies of the child's birth. I t is believed in many parts of Albania that excessive pain, the difficulties and the other consequences of childbirth result from carel ess acts or transgressions committed by the woman during her pregnancy. T he birth thus acts as an agency, revealing the latent tensions and disagreements not only between spouses or between parents and children, but more importantly between male and female within the family and domestic group and hence between in-laws. Certainly on the whole the birth brings out in this case a great number of effects having to do with conscious or unconscious fantasies. But the whole network of family and kin relations suddenly finds itself implicated.

A ccording to an attitude common in the anthropological literature on the subject, and not only that concerning E uropean societies, responsibility for a difficult birth is blamed on the expectant mother through rationalisation about unfaithfulness to her husband. A mong Albanians, on the contrary, people are more inclined to believe that the young woman has been careless with her housekeeping, particularly in those tasks most closely connected with the well-being and existence of the family and kin group: housework, cooking, looking after the livestock, etc. D ifficulty in giving birth is perceived above all as the social sanction, inscribed in the body, of acts that break the law, that stray from the norm and cross boundaries that are always tightly circumscribed. However, rather than speak about a sanction, which implies primarily the idea of punishment, it would be better to talk about consequences, about an immediate transcription.

In the T etova Highlands, to deliver the child that is to be born from the harmful bonds that were believed to hinder its birth, the woman in labour was led to the bread trough where she was supposed to confess her errors and beg pardon. She was next led before all the domestic animals to ask their forgiveness and blessing. Then she was led before the plough-ox, the bell-sheep or bell-ram, which she would kiss three times on 
the forehead between the horns, asking it to deliver her from the suffering of childbirth (Suleimani, 1988: 21). L ater influences from the universalistic religions, Christianity or I slam, may have crept into these beliefs and customs, since in the end G od is also called upon. N evertheless these beliefs attest to a mystical conception of the world, associated above all with people's daily tasks and life, while proving the cohesive bonds within the family and kin group.

The direct outcome of childbirth can apply to the woman who has violated the norm or to the group as a whole. I ts effects make themsel ves felt on other levels as well through a sort of direct metaphoric or metonymic transfer from one to the other. B read and livestock are the staples of the group's livelihood, whereas the birth of a child ensures no more than the group's continuation. $\mathrm{N}$ evertheless, taken together they all project a magnificent image of fecundity par excellence. The plough-ox, even though castrated, represents a fertility principle through the ploughshare that turns the earth. The bell-ram or bellsheep is none other than the impregnator of the flock. Bread, the plough-ox and the bell-sheep, in Albanian culture, are always the bearers of a veritable cult of the family and kin group, and are thus endowed with the right to enable, integrate and protect its continuation.

It is therefore always important to signify and above all to compensate breaches in the order and equilibrium of the world. As in other societies studied by anthropologists, the discourse on the causes of sterility, like the more latent discourse on the causes of fertility, expresses a homology of nature between the natural world, the individual body and society, as well as the possibility of transfers from one level to another (Heritier, 1996: 87-132). This homology is couched in variable symbolic representations, but in accordance with identical formal laws. All three domains - biological, social and natural (animal or material) - are seen as being closely intertwined. Beginning with the perceptible properties of things, people have al ways constructed systems of interpretation that express at the same time his need to organise social relations, to create a system of moral conduct and to solve the problem of their position in the natural world (T ambiah, 1969).

Perhaps most important in Albanian culture is the fact that there is a possibility of the real difficulties encountered in childbirth having harmful consequences for the child's later development. A series of symbolic practices, based on analogical reasoning, is therefore undertaken to soothe the woman in labour by relieving, however little, the difficulties of the birth. I t was firmly believed that this would avoid effects detrimental to the child. Ritual help in childbirth is at the same time closely bound up with a design for the construction of the person and the socialisation of the newborn child with respect to its sex. As for the symbolic procedures, they are probably not essentially very different from the shaman's cure described by L évi-Strauss in his famous article on the 'E ffectiveness of Symbols' (1949).

There is no question of going on to claim that the labour of Albanian women is supposed as 'easy' as that of the native women of Central and South America, which would be only subscribing to the myth of the 'noble savage' in European ground (cf. Wall, 1996). N evertheless, when the long moments of labour become unbearable, but also because of tradition, in the region of $L$ uma, near $K$ ukës in northern Albania, for 
instance, certain objects are held up in turn to the woman in labour, notably the rifle and the distaff, designed to be used by a male child or a female child when he or she grows up (H oxha, 1961). I n some cases, the woman is supposed reach out and touch these objects, or get up and step over them. The stepping over, like the stepping back in the other direction is symbolically connected with the fate of the person concerned. Through the ritual formulae recited by the midwife, the child coming into the world is invited to seize the object emblematic of its sex. All of this is meant to hasten and facilitate the birth (D oja, 1991: 56).
Në kofsh gjalë, If you are a boy,
kap pushkën, then seize your rifle!
nё kofsh cucë, If you are a girl,
kap furkën! then seize your distaff!

In the cure performed by the Cuna I ndians of Panama and described by L évi-Strauss:

'T he shamans were trying to induce the sick woman - whose contact with reality is no doubt impaired and whose sensitivity is exacerbated - to relive the initial situation through pain, in a very precise and intense way, and to become psychologically aware of its smallest details', while this situation sets off a series of events of which the body and internal organs of the sick woman will be the assumed setting. (L évi-Strauss; 1949: 213[193]).

In the A lbanian exorcism, the older woman attempts to induce the sick woman to likewise relive a final situation and effectively test the main tangible details. T his situation projects a sequence of events of which the results of her effort will be the leading actor. According to another version, we see a highly detailed representation of this final situation ( $D$ oja, 1991: 57):

$\begin{array}{ll}\text { N'kofsh gjalë, } & \text { If you are a boy, } \\ \text { del merre spatën } & \text { go and get your hatchet, } \\ \text { e shko n'mal, me ba dru! } & \text { and set off for the mountains to chop wood! } \\ N^{\prime} \text { 'kofsh gjalë, } & \text { If you are a boy, } \\ \text { del merre briskin e rrauju! } & \text { go and get your razor to shave! } \\ N^{\prime} \text { kofsh gjalë, } & \text { If you are a boy, } \\ \text { del merre thuprën e kërlikit } & \text { go and get your shepherd's crook } \\ \text { e shko rauj dhent! } & \text { and set off to guard your sheep! } \\ \text { N'kofsh caucë, } & \text { If you are a girl, } \\ \text { del merre furkën e tajrr! } & \text { go and get your distaff and spin! } \\ N^{\prime} \text { 'kofsh caucë, } & \text { If you are a girl, } \\ \text { del merre shkopin e petës e ftallo! } & \text { go and get your roller and roll the dough! }\end{array}$

In another text that oral tradition dates to somewhere in the second half of the eighteenth century, the midwife attempts to induce the sick woman to relive, in more or less the same fashion, another, equally final situation. This other situation projects a series of events that calls into question the social relations between herself and the patient's family group (D oja, 1991: 48):

Në na i leftë-o, nuses djalë-e, lum ovurdja çka për të marrë! Në na i leftë-o, nuses vajzë-e,
Should the bride give birth to a boy,

Blithe is the matron who takes care of her!

Should the bride give birth to a girl, 
mjer ovurdja çka për të marrë! Na $i$ ka lemun-o, nuses djalë-e, lum ovurdja çka për të marrë!
Bothered is the matron who takes care of her!

The bride gave birth to a boy,

Blithe was the matron who took care of her!

F rom the synopsis $L$ évi-Strauss gives, the A merindian song seems to be a fairly common model.

The sick woman suffers because she has lost her spiritual double, or more correctly one of the specific doubles which together constitute her vital strength. The shaman, assisted by his tutelary spirits, undertakes a journey to the supernatural world in order to snatch the double from the malevolent spirit who has captured it; by restoring it to its owner, he achieves the cure.

$\mathrm{N}$ ow, to the native mind these are not simply

A mythical itinerary and dwelling-place. They represent, literally, the vagina and the uterus of the pregnant woman, which are explored by the shaman and [his tutelary spirits] and in whose depths they wage their victorious combat. ... In a different delivery the 'soul' of the uterus has led astray all the 'souls' belonging to other parts of the body. Once these souls are liberated, the soul of the uterus can and must resume its cooperation. (L évi-Strauss, 1949: 207-209[188-190])

F urthermore, the native ideology of the Cunas 'delineates the emotional content of the physiological disturbance, as it might appear, in an implicit way, to the mind of the sick woman' (L évi-Strauss, 1949: 209[190]). In another Albanian text (N opcsa, 1923), it appears that the Albanian ideology delineates in equal detail the social, rather than emotional, content of the physiological exploit, as it appears, equally implicitly, to the conscious mind this time, not of the sick woman but of the social group:

$\begin{array}{ll}\text { Margjel Tuzja pith mllija } & \text { M argjel T uzja, oh vulva of a turtledove, } \\ \text { turra vrap po shkon ka vija } & \text { hastens, running along the riverside, } \\ \text { shkon ka vija kodrës Mjalts } & \text { Runs along the river up to H oney H ill! } \\ \text { se na } \text { i ka le ni djalë kunatës, } & \mathrm{H} \text { er sister-in-law gave birth to a boy, } \\ \text { nër dullija, nër lejthin } & \text { amidst the juniper and hazel trees, } \\ \text { Prena Tuzit preu kërthin } & \text { Cut the navel of Prena T uzi. } \\ \text { Lala Mark zerna ven! } & \text { U ncle M ark is taking his seat, } \\ \text { zerna ven për darkët natës } & \text { taking his seat for a feast! } \\ \text { se na } \text { i ka le ni djalë kunatës, } & \mathrm{H} \text { is sister-in-law gave birth to a boy, } \\ \text { mori kunat, mori divane! } & \text { oh sister-in-law, oh noble house! } \\ \text { shumë kobin na e bane, } & \text { much amazement did she cause, } \\ \text { shtat vogël e pith madhe! } & \text { slender figure and large vulva! }\end{array}$

In this text, all of the terms of the interpretation are reversed. In the Indian cure '[a] transition will thus be made from the most prosaic reality to myth, from the physical universe to the physiological universe, from the external world to the internal body' (L évi-Strauss, 1949: 213[193]). I n A lbanian practice, the transition begins with the myth and moves towards reality, it proceeds from the physiological universe to the social universe, from the internal body to the external world. $\mathrm{N}$ or is the assistance given the Albanian woman underpinned by any 'psychophysiological mythology' as in the case of the Indian cure, but by a psychosocial mythology, which L évi-Strauss would no doubt have attributed to the same cure if a second technique, in the version available to him, had not 'remained undeveloped' (1949: 217[197]). 
In the A Ibanian case, the psychosocial mythology underpinning the symbolic assistance in childbirth is indicated by the prospect of socialisation. The social myth that is enacted outside the physiological body and in view of the future thus retains its full intensity, its full character as a tangible lived experience, as well as a great affective importance. This is aided by a pathological state, as in the I ndian cure, over which the Albanian practice has laid its own conditions through the use of atechnique, thistime not of internalisation but of anticipated externalisation. I $n$ this case, the system that $L$ évi-Strauss hoped to construct in the version he analysed will be shown to be al ready constructed in the A lbanian case. $T$ he effectiveness of the symbol, in the A Ibanian practice, is thus experienced even before its results can be expected. I $t$ is not at the end, but at the beginning, that the sick woman is presented with the outcome, in other words with the situation in which all of the actors are in their rightful place, restored to a cultural and social order that is no longer threatened by the unleashed forces of physiological nature. The older woman thus provides the young one with the transition to a verbal, but al so tactile and gestural expression, which, as in the Indian case, enables her to undergo her present experience in an ordered and intelligible form, without which it would be chaotic and inexpressible. I is this transition that 'induces the release of the physiological process, that is the reorganization, in a favorable direction, of the process to which the sick woman is subjected' (L évi-Strauss, 1949: 218[198]). And it is in this new language, as L evi-Strauss would say, that both the unexpressed and the otherwise inexpressible states of the prospect of the personalisation and socialisation of the child to be born find immediate expression.

T hrough these practices, Albanians seek not only to ease the difficulties of childbirth, but above all to ensure that the boy grows up to be brave, well brought up and capable of coping with a man's work. The girl will be raised to become skilled in handiwork and housekeeping. Similar rituals are performed later, once the child is born. I $n$ the villages of the $L$ uma region, for example, a rifle is touched to thenewborn boy's hands so that hewill be brave, just as more recently a pencil is used so that he will become educated, whereas the distaff and knitting needles are touched to the girl's hands (H oxha, 1961: 245-253).

In the birth celebration, as well as the other ceremonies, one also observes ritual divination to predict the directions the infant will take in adult life. A series of objects is held out to the child representing different occupations, with symbolism of a rather urban, bourgeois character ( $D$ oja, 1998: 97-101). T he first object the child touches reveals its destiny and its future occupation. I n other societies studied by anthropologists, the same ritual seems to be central to the ideological construction of the society. In effect, it marks the very essence of local theories of identity, which is identification of the reincarnation. F or instance, among the L ebu of Senegal, the child is presented with various objects having belonged to different members of the family; the object chosen determines the identity of the ancestor who is reincarnated in the newborn child (R abain, 1979: 190).

\section{Heroic patterns}

Some of the practices and ritual forms of oral expression performed right after the birth also have an epic character (R eka, 1989). By means of their cultural traditions, the family 
and kin group seek to protect and reassure both the new mother and the baby, especially in the face of the forces of evil, so as to ensure the victory of life (D oja, 1991: 60).

$\begin{array}{ll}\text { Daçe, përdaçe, } & \text { Scatter it about, } \\ \text { diçe, përdiçe; } & \text { Send it a-flying; } \\ \text { për hair na goftë, } & \text { may it be a blessing, } \\ \text { rroftë e trashëgoftë! } & \text { M ay he grow and have children! }\end{array}$

Among other things, these traditions introduce the image of the participation of the destructive forces and unleash natural elements - fire and wind, of lightning and thunder elements of explosion and of rectification, symbolised in the birth of the male child (D oja, 1991: 61):

Friu era mal më mal $-e$, The wind blew through the mountains, nusja jon' do bë̈ё djalë; our bride is to give birth to a son;

friu era dhe na ngriti, nusja nonë seç briti, djalin në shesh e vërviti; friu era dhe na ngriti, pjella jonë ulurijti, the wind blew and caused us to rise, H ow our bride did cry out, As she cast the lad onto the ground; the wind blew and caused us to rise, the infant started crying, s'ishte vajzë, po qe djalë, djalë me yllin në ballë! it was not a girl, it was a boy, a lad with a star shining on his brow.

T he birth act is also represented in its social and cosmic dimensions, like the new mother, human and heroic, attributes inseparable from her person and from the life to which she gives birth. I ndeed different myths tell the adventures of culture heroes who display prodigious strength due, notably, to their 'heroic' birth.

The epic and heroic character of birth in A lbanian tradition is al so to be seen in relation to the symbolic configuration of fire, which shifts its thermal energy towards an erotic passion. I n the anagogical nature of lightning symbols devel oped by F razer, it is possible to see the substitution of lightning for the father's semen in the womb of the mother whose product develops by explosion (Belmont, 1973). T hese images resemble a pattern of cyclical rhythms and synthetic structures that enable the transition from production by friction, rotation and explosion to heated products, namely the cultural products of cooking, and the biological and social products of human reproduction (D urand, 1969). In this overall symbolism, each new birth is merely a specific 'product' in which the thermal and erotic images are fashioned into not only synthetic but also heroic structures, as in the previously cited example.

$\begin{array}{ll}\begin{array}{l}\text { Nusja nonë sec briti, } \\ \text { djalin në shesh e vërviti; }\end{array} & \text { A ow our bride did cry out, } \\ \text { friu era dhe na ngriti, } & \text { the wind blew and caused us to rise, } \\ \text { pjella jonë ulurijti. } & \text { the infant started crying, }\end{array}$

These images represent not only tactile intercorporal attributes, but also a visual sensibility, which links them to the symbolism of light and lightning, in other words to the 'masculine' configurations of all illumination:

S'ishte vajzë, po qe djalë, It was not a girl, it was a boy, djalë me yllin në ballë. $\quad$ a lad with a star shining on his brow. 
Other documents feature the same representations with the same intensity (Doja, 1991: 62).

Tё djelë qё mё saba, E arly Sunday morning,

ç'u këput një yll e ra! a star detached itself and fell to earth!

I $n$ the north, the first thing the midwife does when arriving to assist the woman in labour is to light a fire in the fireplace. If the fire catches immediately and illuminates the room, it is presumed that the child will be a boy. A fter the birth, the room where the mother and the infant lie is kept lighted all night for several nights or weeks (G jeçov, [1933]1989: 433-436). T his says a lot about this society that, at the time, still used pitch torches for lighting.

The symbolic images of the collective representations of birth are thus imbued, by means of the cultural forms of oral expression, with fire symbols in the configurations of a lightning bolt, the crash of thunder and the spark that ignites the gunpowder (D oja, 1991: 70).

$\begin{array}{ll}\text { Ani krisi pushka, bani bum, } & \text { Y es, the rifles fired, boom, boom } \\ \text { na ka le ni djalë n'katun; } & \text { A boy was born in our village; } \\ \text { lejti i vogël sa ni gogël, } & \text { born tiny as an acorn, } \\ \text { po na gzoi t'madh e t'vogël! } & \text { all rejoiced, young and old! }\end{array}$

In certain cases, the announcement of the birth of a male child reveals the conceptions concerning the gender division. In the south, the birth of a boy is announced to both the father and the mother of the new mother, while the birth of a girl is announced only to her mother. In the north, no noise is made for the birth of girls, no announcement, except when the news is learned by chance; whereas the birth of a boy is announced by firing guns, so that everyone may hear about it, the kin group, the neighbourhood and the village. T he guns are shot towards the sun at the same time as the women and girls of the household sing at the top of their voices while making a great noise with their tambourines and other instruments (D oja, 1991: 69-71).

I t is only in recent times that this custom has come to show the general enthusiasm, joy and jubilation of the family and kin group. O riginally it was meant to recall the apotropaic act of man in his perpetual struggle against the forces of destruction that were believed to be directed with particular malevolence at the child. At the same time, gunshots, like lightning, are connected with the heroic structure of birth symbols in general.

When the birth is announced by the firing of guns, it is usually the men who fire, but in the region of D renice, in K osova, it also happens that women too fire shots, especially young women in their first year of marriage, with the explicit aim of fertility (Pirraku, 1978). A ccording to other sources of information, the gunshots fired during a wedding, when the bride goes by, imply that she will have plenty of milk and that it will come readily (D ojaka, 1986). And in most places, people who sing out of tune and loudly are told to keep quiet because the racket will make it rain.

A nother example of the Albanians' conventional attitudes suggests the same relationship between singing and fertility by way of rain. I $n$ the region of $L$ abëria in southwestern Albania, each village still cultivates a vocal art, whose strange harmonies, close complicity and almost mystical absorption recall the polyphonic music of Corsica 
and Sardinia, in Western Europe. Farmers, shepherds and craftsmen carry on the tradition inherited from their ancestors, singing at betrothals, weddings and village celebrations for the sheer pleasure of hearing their voices intertwine with the generous well-timbred and expertly vocalised voice of the drone. $\mathrm{N}$ evertheless, the singing style of $L$ abëria, with its strong contrasts and its highly elaborate polyphonic and contrapuntal development, can sound like a racket to unfamiliar ears. Someone from outside the region has only to hear this singing to believe that it probably does bring rain.

The collective representations and their symbolic expressions are deeply suffused with the thermal and aquatic symbolism of fertility, with the erotic and masculine images of fire, light and rain, all of which suggest themselves as metaphorical configurations of birth. $T$ he symbolic representation thus transposes, on the one hand, images of fertility and, on the other, those of purification. T hese polyvalent images make the birth of the male child the symbol of radical transformation, rebirth and regeneration (D oja, 1991: 68).

Krisi pushka, leu djali, Rifles are firing, a son has been born, mugalloi dushk e bar, oak leaves and grass are beginning to grow, edhe zogu knon në mal. and the birds are singing in the mountains.

T he general meaning that emerges from this imagery is the regeneration of life seen as a renewal of the natural environment. The world of nature situated on the boundary between the wilderness and cultivated land, on the other side of the territory occupied by human dwellings and agriculture yet slightly this side of the vast wilderness, domain of ferocious beasts and supernatural beings, is the mythical model of birth, another site par excellence where gestation takes place (Belmont, 1980). T he gunshot expresses optimistic joy and, in general, the prediction and hope of a favourable destiny and a happy future. It marks the growth of the family and kin group through new births, marks the increase in the number of arms to work and fight. The sprouting grasses and budding woods recall the miracle of nature's springtime. T he birdsong poetically expresses a joy in good fortune and a happy destiny. The same images also demonstrate a solid and practical bond between the plant and animal kingdoms, and the infant who, by its birth, marks the transition to the adult social status, whose symbolic insignia in Albanian culture is the right to carry a gun. T his configuration is closely bound up with and conditioned by the development of life, its renewal and its miraculous periodical cycles, symbolised by gunshots, birth, germination and song.

\section{References}

Bachelard, G aston. 1942. L'eau et les rêves: essai sur l'imagination de la matière (Paris).

Bachelard, G aston. 1948. La terre et les rêveries de la volonté (Paris).

Belmont, N icole. 1971. Les signes de la naissance: étude des représentations symboliques associées aux naissances singulières (Paris).

Belmont, N icole. 1973. 'L evana, ou comment 'élever' les enfants'. Annales: Économies, Sociétés, Civilisations, 28 (1), 77-89.

Belmont, N icole. 1980. 'L'enfant exposé', Anthropologie et Sociétés, 4 (2), 1-17.

Bloch, M aurice. 1993. 'Zafimaniry birth and kinship theory', Social Anthropology: Fournal of the European Association of Social Anthropologists, 1 (1b), 119-32.

Byrnes, Robert F . (ed.) 1976. Communal families in the Balkans: the zadruga (N otre D ame, Ind.). 
Çabej, Eqrem. 1935. 'Sitten und Gebräuche der Albaner', Revue Internationale des Études Balkaniques, 2 (1), 556-72.

Cozzi, Ernesto. 1910. 'L a Vendetta del sangue nelle M ontagne dell'Alta Albania', Anthropos: International Review of Anthropology and Linguistics, 5, 654-87.

Doja, Albert. 1988. Proza Popullore, vol. 6. (T irana) Akademia e Shkencave (T rashëgimia K ulturore Shqiptare, Folklore I ). [I n collaboration with J. Panajoti and A. X hagolli].

D oja, Albert. 1990. 'Aspekte të pasqyrimit të marrëdhënieve shoqërore në folklorin e lindjes', Kultura Popullore, 11 (2), 53-68.

D oja, Albert. 1991. Këngë të lindjes dhe ninulla (T irana) Akademia e Shkencave (T rashëgimia K ulturore Shqiptare, F ol klore IV, L irika Popullore, 4). [I n collaboration with K . V asili].

D oja, Albert. 1998. 'Évolution et folklorisation des traditions culturelles', East European Quarterly, 32 (1), 95-126.

Doja, Albert. 1999. 'M orphologie traditionnelle de la societé albanaise', Social Anthropology: Fournal of the European Association of Social Anthropologists, 7 (1), 37-55.

D ojaka, A baz. 1986. Martesa në Shqipëri (T irana).

D umezil, G eorges. 1987. La Religion romaine archä̈qu. 2e edition (Paris).

$\mathrm{D}$ urand, G ilbert. 1969. Les structures anthropologiques de l'imaginaire: introduction à l'archétypologie générale (Paris).

D urham, M. Edith. 1928. Some Tribel Origins, Laws and Customs of the Balkans (L ondon).

Eliade, M ircea. 1949. Traité d'histoire des religions (Paris).

F rashëri, Stavro S. 1936. Folklor shqiptar (D urrës).

Giordano, Agostino. 1976. Nascita e prima infanzia del bambino nella tradizione folclorica di Frascineto-Ejanina (Cosenza) (Zëri i A rbëreshvet, 9).

G jeçov, Shtjefen K. [1933]1989. Kanuni $i$ Lekë Dukagjinit (ed) K. N ova. Expanded edition (T irana) Akademia e Shkencave (T rashëgimia K ulturore Shqiptare, e D rejta Zakonore, 1). [1933 edition translated into I talian, R oma: Reale A cademia 1941; G erman, in: Zeitschrift für vergleichende Rechtswissenschaft 54-56, 1954-1958, reprint Peja: Dukagjini Publishing 2001; Bilingual Albanian-English, New Y ork: Gjonlekaj Publishing 1989; F rench, Peja: Dukagjini Publishing 2001].

$\mathrm{G}$ riaule, M arcel and G ermaine D ieterlen. 1951. Les signes graphiques soudanais (Paris).

H axhihasani, Q emal. 1988. Këngë rituale dhe të punës (T irana) A kademia e Shkencave (T rashëgimia $\mathrm{K}$ ulturore Shqiptare, Folklore, IV -1). [I n collaboration with K . Vasili].

$\mathrm{H}$ eritier, $\mathrm{F}$ rançoise. 1996. Masculin/féminin: la pensée de la différence (Paris).

H oxha, Shefqet. 1961. L indja në L umë. Buletin $i$ Universitetit Shtetëror të Tiranës: Seria Shkencat Shoqërore, 15 (2), 245-53.

L eroi-G ourhan, André. 1964. Le geste et la parole (1. T echnique et langage, 2. L a mémoire et les rythmes) (Paris).

L évi-Strauss, Claude. 1949. 'L 'efficacité symbolique', in Anthropologie structurale (Paris) 1958, 205-26. English translation (N ew Y ork, 1963), 186-205.

L évi-Strauss, Claude. 1956. 'L afamille', in Le regard éloigné (Paris) 1983, 65-92. English translation (N ew Y ork, 1985), 39-62.

L évi-Strauss, Claude. 1984. Paroles données (Paris). English translation, Anthropology and Myth: Lectures, 1951-1982 (Oxford, N ew Y ork, 1987).

L oux, F rançoise. 1979. Pratiques et savoirs populaires: le corps dans la société traditionnelle (Paris).

N opcsa, Franzs. 1923. Albanien: Religiose Anschauungen, Sitten und Gebräuche (Wien) Österreichische $\mathrm{N}$ ational bibliothek, Photomanuscript: 1263-63/9393.

Pirraku, M uhamet. 1978. 'T ëdhëna mbi traditën e pagëzimit nëD renicë', Gjurmime Albanologjike: Folklor dhe Etnologii, 6, 127-44.

R abain, J acqueline. 1979. L'Enfant du lignage: du sevrage à la classe d'âge chez les Wolof du Sénégal (Paris).

Rank, Otto. [1909]1952. The Myth of the Birth of the Hero: A Psychological Exploration of Myth (N ew Y ork). 
R eka, F anie. 1989. 'R reth këngëve të lindjes', Çështje të folklorit shqiptar, 4, 221-237.

Shala, D emush. 1983. Letërsia popullore (Prishtina, K osova).

Sicard, Emile. 1943. La Zadruga sud-slave dans l'évolution du groupe domestique (Paris).

Stahl, Paul-H enri. 1981. 'L es enfants et la pérennité dela maisnie: quelques exemples balkaniques', Revue des Études Roumaines, 16, 47-62.

Suleimani, F adil. 1988. Lindja, martesa dhe mortja në Malësinë e Tetovës (Prishtina, K osova).

T ambiah, Stanley J. 1969[1985]. 'A nimals are Good to Think with and Good to Prohibit', in Culture, Thought, and Social Action: An Anthropological Perspective (Cambridge, M ass.), 169211.

T irta, M ark. 2004. Mitologjia ndër Shqiptarë (T irana).

Vlahovic, Petar. 1971. Obiçaji, verovania i praznoverice naroda fugoslavije (B eograd). [Alb. transl. manuscript in I nstitute of F olk Culture, T irana].

W all, L . L ewis. 1996. 'T he noble savage in labor or Claude L evi-Strauss has a baby', Perspectives in Biology and Medicine, 40 (1), 33-44.

Zenku, A bedin. 1972. 'V igjia', Jehona, 11 (6), 105-111. 